\title{
Influence of Zinc oxide on Direct Injection CI Engine Fueled With Waste Cooking Oil Biodiesel
}

\author{
Ashley Lobo $^{1 *}$, D K Ramesha ${ }^{2}$, Manjunath ${ }^{2}$ \\ Department of Mechanical Engineering, Dayananda Sagar College of Engineering, Bengaluru, Karnataka ${ }^{1}$ \\ Department of Mechanical Engineering, University Visvesvaraya College of Engineering, Bangalore University, \\ Bengaluru, Karnataka ${ }^{2}$
}

\begin{abstract}
With advancement in technology and production of nanosized particles, access and more importantly cost of nanoparticles have come down. This gives an exciting opportunity to tackle the strict regulations for emissons being in place which poses an urgent need to reduce emissons of not only new vehicles but of existing vehicles with as little external modification of the engine as required. Not a lot of extensive work has been conducted in terms of emissons, combustion and performance characteristics of fuels mixed with metallic nanosized powders. Zinc oxide is one such exciting nanoparticle because of its properties such as improvement of heat transfer rate, flash point, fire point, ability to store energy in it crevices and mass diffusivity, when dispersed in any fluid medium. And also it increases catalytic properties and provided higher surface to volume ratio. In the present work the Biodiesel derived from waste cooking oil (WCO) has been employed as fuel along with $80 \mathrm{ppm} \mathrm{ZnO}$ and is considered for investigation. A Kirloskar made TV2 diesel engine has been employed to conduct the experiment at varied load. In this experiment Diesel has been considered as baseline reading and two other fuels, that is Biodiesel and Biodiesel+80ppm of $\mathrm{ZnO}$ has been considered for comparison purpose. The engine has been run from $0 \%$ to $100 \%$ load using the 3 fuels and the results have been evaluated, tabulated and plotted on graphs for discussion. From the results it is revealed that the BTE is increased by nearly $4 \%$ and BSFC has reduced by $9 \%$ thus showing that the performance of the engine is improved .The emissions of CO, NOx and PM has reduced and especially CO has reduced by nearly $30 \%$.There is also improvement of combustion with the HRR increasing by nearly $11 \%$ and introduction of ignition delay. Thus by employing this additive the emissons are decreased without penalizing the performance and combustion characteristics
\end{abstract}

Keywords: Emissions, Waste Cooking Oil, Biodiesel, Performance, Zinc Oxide, Combustion, NOx, Nanoparticle

\section{INTRODUCTION}

Biodiesel is alkyl esters of fatty acid which are gotten from transesterification and its performance is comparable to diesel thus it can be used as an effective tool to combat the exponential decrease of fossil fuels in the oil reserves. Biodiesel can be gotten from a renewable source and requires no hardware alteration for application [1,2] A major stimulus for increased Biodiesel consumption is the fact that it reduces emissions which are one of the shortcoming of diesel engines. It does this by increasing the oxygen content in the fuel which leads to better overall combustion and is extremely useful for curtailing NOx formation. Use of biodiesel has been on the rise especially in the European Union because it reduces dependency on fossil fuels and helps shrink greenhouse gas effect, and this usage is also motivated to meet the targets set by the European Parliament. Waste Cooking Oil (WCO) is one of the main sources for biodiesel production [3].Collation of WCO from different sources result in heterogeneous feedstock streams, and standardizing the characteristics of WCO is therefore inherently difficult. High-grade waste vegetable oils that are deemed safe for consumption by animals outside of the EU (and are therefore not waste materials) are redirected from animal feed to biofuel production as suppliers will pay more for a waste-derived biofuel than they would for virgin oil [4]. Between 2011 and 2016, the utilization of WCO has increased steadily, resulting in a 360\% rise in its use, increasing from 680,000 tonnes to 2.44 million tonnes [5]. With the application of biodiesel, there are disadvantages such as high density and lower calorific value. Fuel additives play a crucial role in curtailing the drawbacks of biodiesel and to make sure it can to make sure it meets the set international fuel standards. Additives are applied to improve the combustion, emission and performance characteristics. Use of nanoparticles as combustion catalyst have demonstrated several benefits like greater burn rates, high combustion enthalpies, upsurge in energy density, shorter ignition delay, better combustion and lower pollution [6]. Nanoscale additives enhance surface area to volume ratio and release nearly double the energy derived from even the best fuel combustion and molecular explosion plus due to their small size they do choke the fuel injector and filer [7] .Metal based additives are effective in reducing because the metals react with 
$\mathrm{H}_{2} \mathrm{O}$ vapor in the exhaust emissions to yield highly reactive hydroxyl $(\mathrm{OH})$ radicals, and also the metals assist as an oxidation catalyst lowering the oxidation temperature for soot leading to improved particle burn out. Nano metal oxide particles plays the role of an oxidation catalyst leading to complete combustion and ignition due to higher carbon combustion activation $[8,10]$. Conductivity indicates the ability of the fuel to dissipate static electrical charges and low conductivity of a fuel is highly undesirable because static electrical charges can accumulate in the fuel, which might result in unexpected sparks. This can be fixed using nanoparticles which develop the conductivity [9]. Increase in viscosity with increased nanoparticle concentration in the fuel. Such high viscosity fuel when passed through injection process forms coarse fuel droplets which adversely affects the fuel penetration and dispersion in the cylinder. The intention behind using Zinc Oxide as the nanoparticle additive is because studies done [11-17] have something lacking in them,

1. If the amount of $\mathrm{ZnO}$ nanoparticle used in experimentation is more it leads to cellular injury and affect the nasal mucosa cells.

2. Or have not performed all 3 tests (Performance, Emissions and Combustion characteristics) together which does not give us the whole picture about the feasibility of using Zinc Oxide as a large scale additive

3. And none of them have done experimentation with Zinc Oxide as additive and Waste cooking oil methyl ester as biodiesel.

\section{PREPARATION OF FUEL AND EXPERIMENTAL SET UP}

\section{A. Fuel Preparation}

Current experimentation work considered transesterification process to obtain biodiesel as shown in Figure 1 [18]. Transesterification process consists of 2 steps namely Acid Transesterification and Base Transesterification. In acid transesterification, $\mathrm{WCO}$ is heated up to $50^{\circ} \mathrm{C}$. Then Methanol is added to preheat WCO. After this reaction the bottom deposit is detached from the reaction (Base Transesterification). The obtained mixture is heated for 45-55 minutes in the presence of $\mathrm{KOH}$ (Potassium Hydroxide) and methanol. Once the reaction is completed, the products are permitted to distinct into two deposits. The bottom deposit, which contained glycerol, is removed. The ester leftovers in the upper deposit. Figure 1 demonstrates the complete operation of the Transesterification method. The fuel properties of Diesel, WCO with and without Zinc Oxide were determined and tested to meet the ASTM standard requirement. Heat value of the fuel is measured by using Bomb Calorimeter, Kinematic viscosity is measured by using Capillary tube Viscosity Test Method, flash point is marked by using open loop method and measured of density is carried out by using two separate measurements of mass and volume. All the properties of verified biofuels are tabulated in Table I.

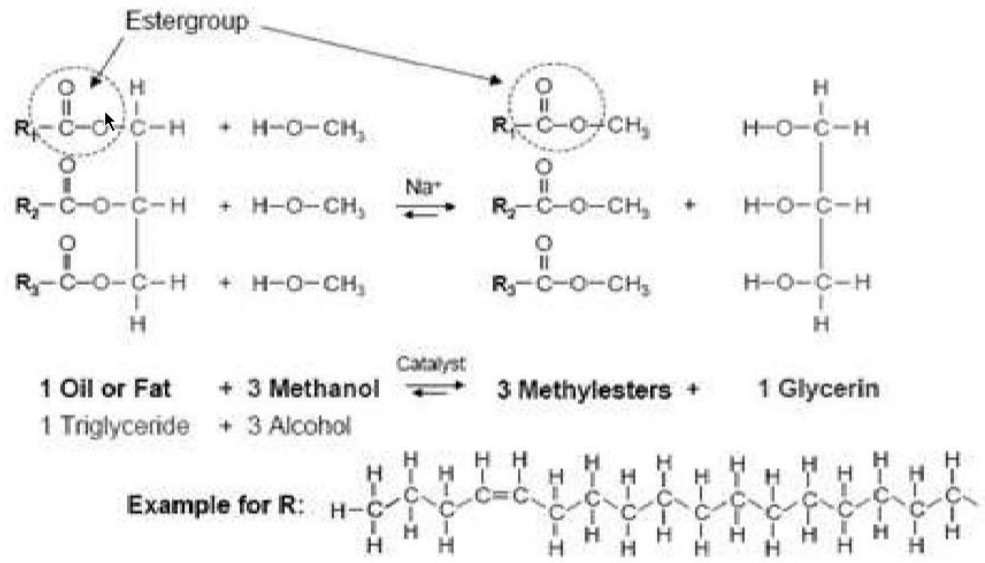

Figure 1: Transesterification of Oil

Table I Properties of Fuels

\begin{tabular}{|l|c|c|c|c|}
\hline \multicolumn{1}{|c|}{ Properties } & Diesel & $\begin{array}{c}\text { WCO (Waste } \\
\text { Cooking Oil) }\end{array}$ & $\begin{array}{c}\text { WCOME (WCO } \\
\text { Methyl Ester) }\end{array}$ & $\begin{array}{c}\text { B20WCOME (20\% } \\
\text { WCOME and 80\%Diesel) }\end{array}$ \\
\hline Kinematic Viscosity(40 ${ }^{\circ} \mathbf{C , C s t )}$ & 3.05 & 43 & 5.83 & 4.01 \\
\hline Heat Value (MK/Kg) & 44.5 & 29 & 38 & 39.2 \\
\hline Density (Kg/m^3) & 830 & 914 & 887 & 842 \\
\hline Flash Point ${ }^{\circ} \mathbf{C}$ & 60 & 307 & 150 & 98 \\
\hline Cetane Number & 40 & 53 & 51.48 & 51.48 \\
\hline Iodine Number(J2g/100g) & 6 & 125 & 59 & 17.42 \\
\hline
\end{tabular}


Nanoparticles are dispersed into a mixture of Waste cooking Oil biodiesel-diesel fuel at the recommended composition of B20 Biodiesel (20\% by vol. of WCO and $80 \%$ of diesel fuel) with the help of an ultrasonicator (Hielscher UP200S40) for 35 minutes at a frequency of $24 \mathrm{kHz}$. The ultrasonication technique is the an ideal method to disperse the nanoparticles in the biodiesel blend to avert the agglomeration of nanoparticles by means of pulsating frequencies to disperse nanometer ranges into the blend [19]. The Zinc Oxide ( $\mathrm{ZnO})$ nanoparticles of average size of 35 to $50 \mathrm{~nm}$ with detailed specifications list in Table II

Table II Zinc Oxide Properties

\begin{tabular}{|l|l|l|}
\hline Sl. No. & Parameters & Zinc Oxide(ZnO) \\
\hline 1 & Manufacturer & Nano Research Lab \\
\hline 2 & Chemical Name & Zinc Oxide \\
\hline 3 & Form Colour & Powder White \\
\hline 4 & Particle Size & $35-50 \mathrm{~nm}$ \\
\hline 5 & Specific Surface Area & $12 \mathrm{~m}^{2} / \mathrm{g}$ \\
\hline 6 & Purity & $99.97 \%$ \\
\hline
\end{tabular}

\section{B. Experimental Setup}

A Kirloskar made TV2 diesel engine has been employed to conduct the experiment at varied load. In this experiment Diesel has been considered as baseline reading and two other fuels, that is B20 (20\% by vol. of WCO and $80 \%$ of diesel fuel) Biodiesel and B20 Biodiesel+ Zinc Oxide has been considered for comparison purpose. The engine has been run from $0 \%$ to $100 \%$ load using the 3 fuels and the results have been evaluated, tabulated and plotted on graphs for discussion.

The experimental results will certainly have error and uncertainties, which can rise from the incorrect calibration of instruments due to excessive handling and mishandling, surrounding conditions, experimental test conditions and planning, surveillance and reading. The errors which are gotten become a hindrance to obtain accurate results. Thus to nullify these errors, tools and methods from mathematics and statistics are used. Generally the method used is repetition of the taking data from the experimentation (at least 3 times) and finding the mean in order to minimize the error which may occur [20] .Measurements of uncertainties were calculated and results are shown in Table III.The uncertainty of the experiment was $1.8445 \%$.

Table III Error Analysis and Uncertainty Table

\begin{tabular}{|l|l|l|}
\hline Measurements & Accuracy & Uncertainty \\
\hline Speed & $\pm 3 \mathrm{RPM}$ & $\pm 0.3 \%$ \\
\hline BSFC & $\pm 3 \mathrm{~kg} / \mathrm{KWh}$ & $\pm 0.35 \%$ \\
\hline Power(KW) & $\pm 0.3 \mathrm{KW}$ & $\pm 0.40 \%$ \\
\hline $\mathrm{CO}$ & $\pm 0.02 \%$ & $\pm 1.0 \%$ \\
\hline NOx & $\pm 7 \mathrm{ppm}$ & $\pm 0.7 \%$ \\
\hline In cylinder pressure & $\pm 0.1 \mathrm{bar}$ & $\pm 0.2 \%$ \\
\hline Temperature & $\pm 1^{\circ} \mathrm{C}$ & $\pm 0.1 \%$ \\
\hline HC & $\pm 7 \mathrm{ppm}$ & $\pm 0.7 \%$ \\
\hline Torque & $\pm 0.1 \mathrm{Nm}$ & $\pm 1 \%$ \\
\hline
\end{tabular}

\section{RESULTS AND DISCUSSION}

Exhaustive experimentation has been conducted with varied load and the readings have been tabulated and plotted in graphs. The different characteristics which was measured of the engine fueled with biodiesel are, performance ( $\mathrm{P}-\theta$ and Heat Release Rate(HRR)), combustion( break thermal efficiency(BTE) and brake specific fuel consumption(BSFC and emissions (nitrogen Oxides(NOx),carbon monoxide(CO),hydrocarbons(HC), smoke opacity)

\section{Heat Release Rate (HRR)}

In the Figure 2 the maximum Heat release rate at full load is represented and its variation with load is shown, the value of HRR is lower by $6 \%$ for $\mathrm{B} 20$ and $11 \%$ for $\mathrm{B} 20+\mathrm{ZnO}$ when compared to diesel at full load. The decrease of HRR is because of lower end temperature of combustion due to lesser calorific value of the blends [17]. The greater cetane number and improved evaporation rate and A-F mixture of the blends result in lower HRR [21]. Also the better surface area/ volume ratio and upgraded ignition properties of nanoparticles cause better combustion of the blends compared diesel leading to inferior value of $\operatorname{HRR}[22,23]$. 


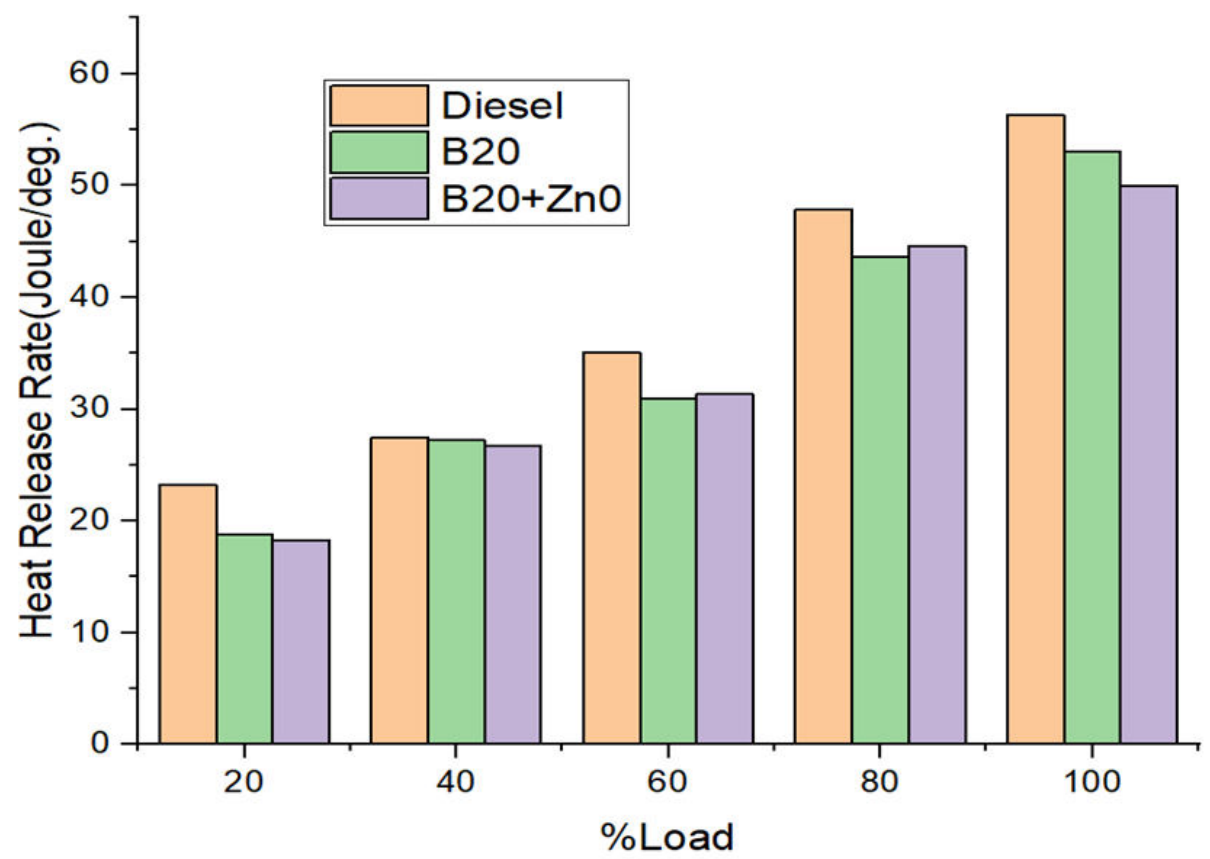

Figure 2: Variation of Heat Release Rate with Load

\section{Pressure-Crank angle $(\mathbf{P}-\boldsymbol{\theta})$}

Figure 3 shows the variation of Pressure with Crank Angle. The peak in-cylinder is lesser 11\% for B20 when compared to diesel at full load and $10 \%$ for $\mathrm{B} 20+\mathrm{ZnO}$. The reduction is a consequence of high viscosity [23]. When the injection pressure is increased, ignition delay decreases and better atomization of fuel takes place [24]. This leads to a smaller accumulation of the fuel in the first phase and results in a decrease of the peak pressure as peak pressure in the cylinder is associated to the quantity of prepared fuel in the first phase .Zinc oxide improves the ignition which causes accelerated combustion and as a result leads to enhanced catalytic activity [24 -26].

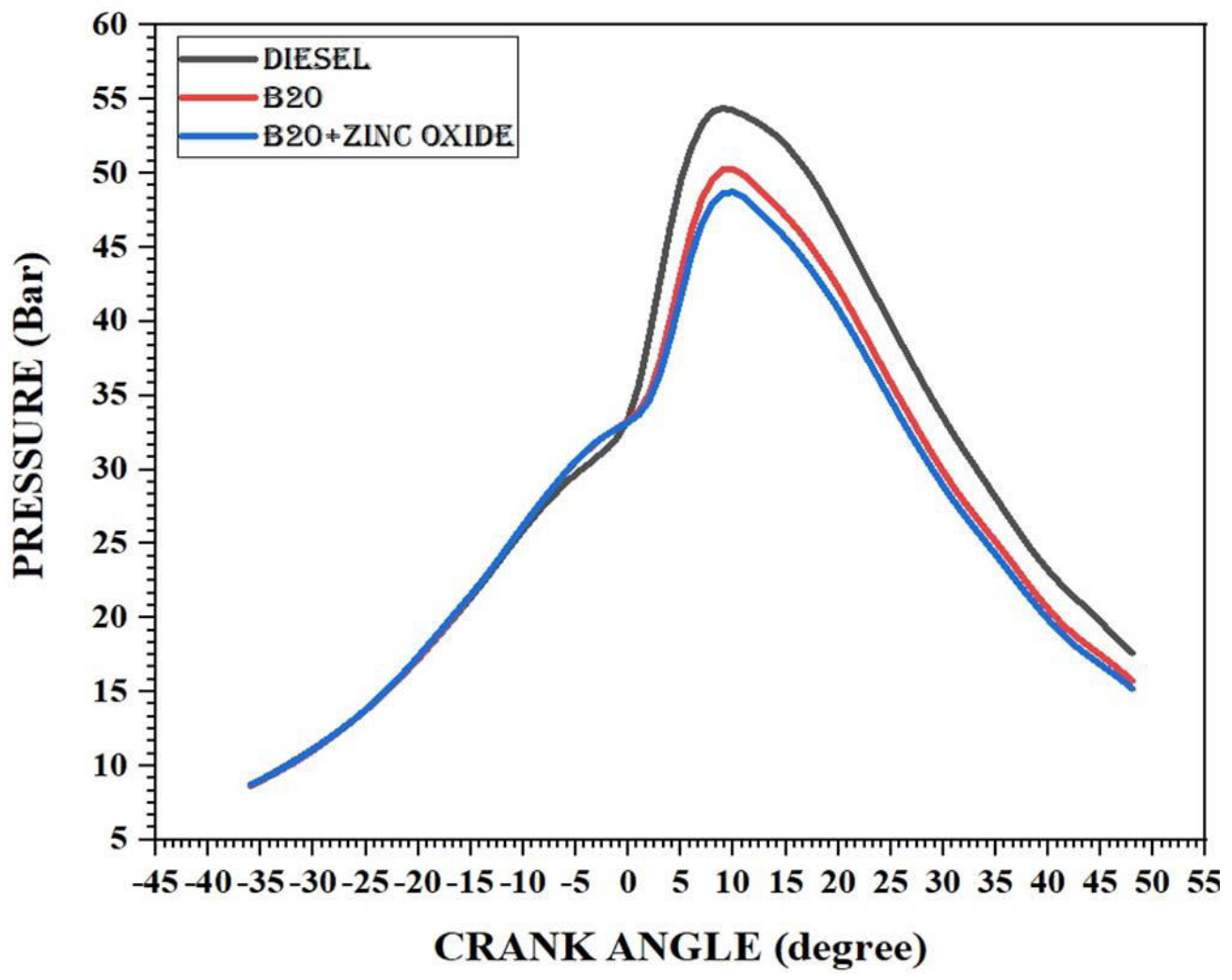

Figure 3: Variation of Pressure with Crank Angle 
3. BSFC(Brake Specific Fuel Consumption)

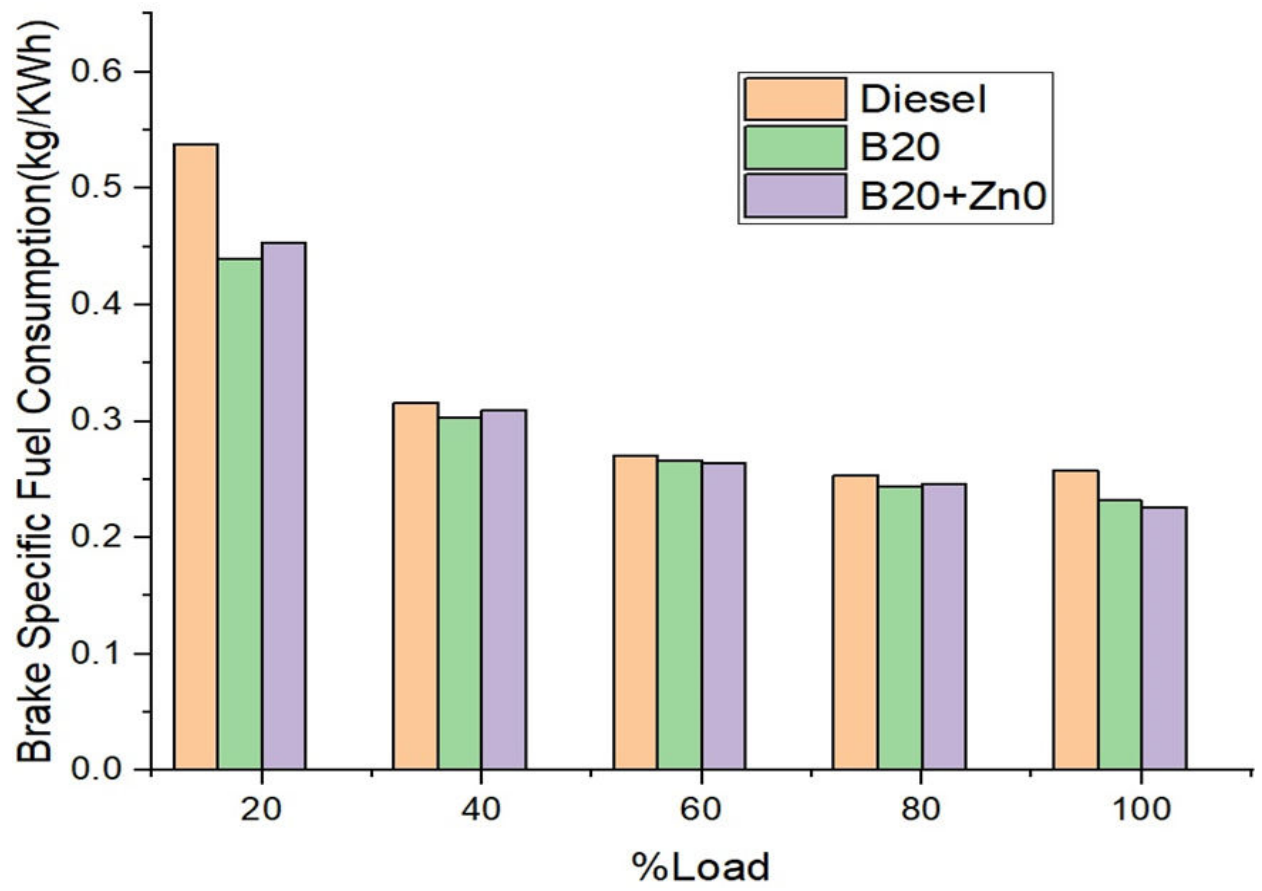

Figure 4: Variation of Break Specific Fuel Consumption with Load

In Figure 4 there is reduction of $10 \%$ for the Brake specific fuel consumption of B20 when compared to diesel at full load and $12 \%$ for $\mathrm{B} 20+\mathrm{ZnO}$. Zinc Oxide acts as an oxidizing agent which boosts the combustion process and improves the A/F Ratio reducing the BSFC [27]. Shorter ignition delay caused by Zinc Oxide leads to better combustion and thus more work is gotten for the same amount of fuel thus lowering the BSFC [28]. ZnO will minimize pour point and increase the flash point properties of the blends which improve atomization and better mixing process reduce BSFC [29] .Nanoparticles have a catalyst effect which lessens oxidation temperature which is instigated from lower oxidation energy with $\mathrm{ZnO}$ [30-33].

\section{Brake Thermal Efficiency (BTE)}

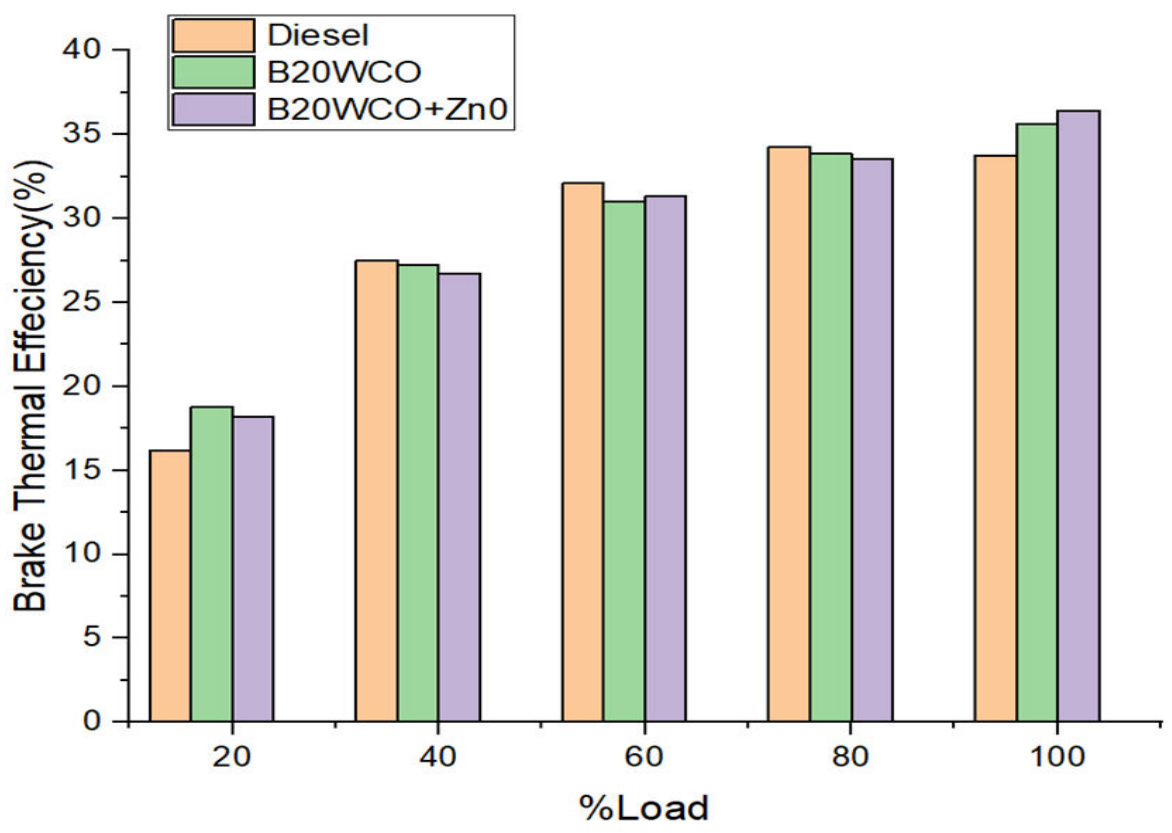

Figure 5: Variation of Break Thermal Efficiency with Load 
From the Figure 5 it can be seen that BTE reduces at all loads except full load BTE reduces. The BTE is reduced because of the occurrence of oxygen buffer of $\mathrm{ZnO}$ which lowers the oxygen requirement for complete combustion process and therefore lower $\mathrm{A} / \mathrm{F}$ ratio for $\mathrm{ZnO}$ addition with biodiesel [34]. Nanoparticles help to split the hydrogen atom from water and which could have participated in the combustion process along with improving the rate of heat conduction which lowers BTE $[23,35]$

\section{5. $\quad$ Nitrogen Oxides (NOx)}

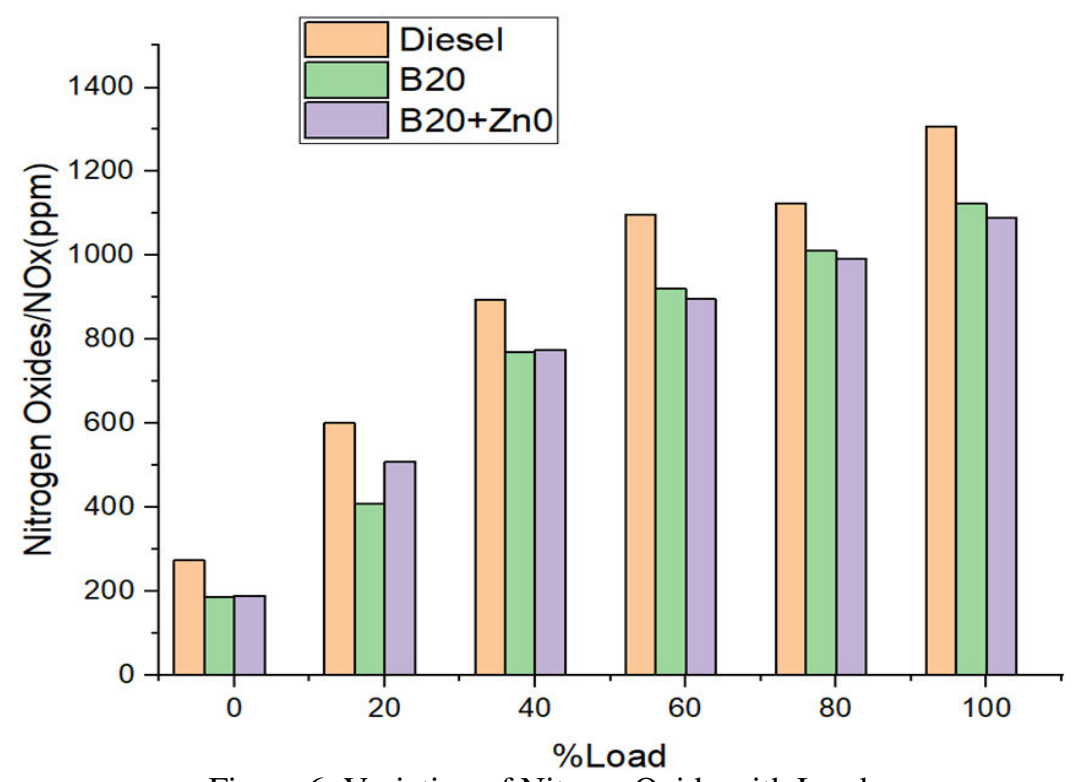

Figure 6: Variation of Nitrous Oxide with Load

Figure 6 shows the variation of Nitrous Oxide with Load. The NOx emissions is reduced by $14 \%$ for B20 bland and $16 \%$ for $\mathrm{B} 20+\mathrm{ZnO}$ compared to diesel. Zinc Oxide increases the average temperature of the combustion chamber (due to improved Calorific value) which leads to greater oxygen in the blend to react leading to lower NOx emissions [36]. $\mathrm{ZnO}$ absorbs oxygen for the reduction of NOx [37]. Better fuel-air mixing cause an oxygen deficit for NOx leading to decrease of NOx emissions. NOx is reduced with the addition of $\mathrm{ZnO}$ being thermally stable which leads to reduction of nitrogen oxide

\section{Carbon Monoxide (CO)}

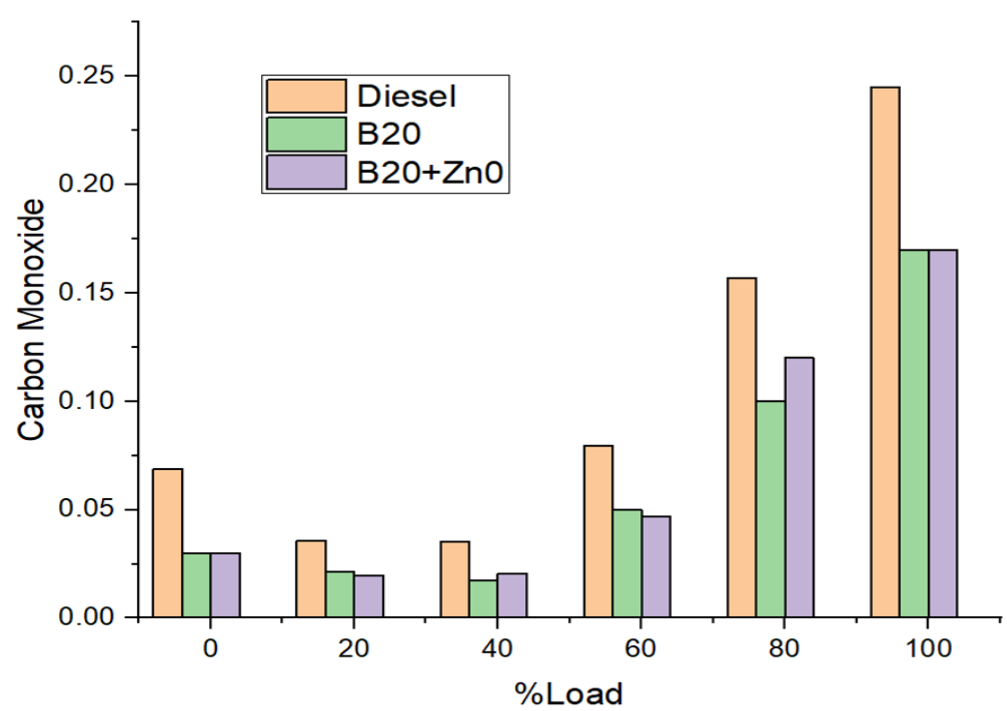

Figure 7: Variation of Carbon Monoxide Emissons with Load

From the Figure 7 it is clear that for full load the CO emissions decrease by nearly $30 \%$ for both the blends B20 and $\mathrm{B} 20+\mathrm{ZnO}$ at full load when compared to the baseline reading of diesel. Presence of ignition delay as explained earlier 
maybe be detrimental to exhaust emissions, because it determines the quantity of the fuel burnt and increasing the burned fuel quantity in the premixed phase decreases $\mathrm{CO}$ emission. Zinc Oxide increases the average temperature of the combustion chamber (due to improved Calorific value) which leads to greater oxygen in the blend to react resulting in lower $\mathrm{CO}$ [38]. ZnO also acts as an oxygen donating catalyst, and provides oxygen for the oxidation of $\mathrm{CO}$ [37] The decrease in $\mathrm{CO}$ emissions is also because by increasing the concentration of additives because of enrichment of oxygen owing to $\mathrm{ZnO}$ and biodiesel addition, increases the air-fuel ratio in the fuel rich regions which leads to better premixed combustion resulting in better complete [28].

\section{Hydrocarbon emissions (HC)}

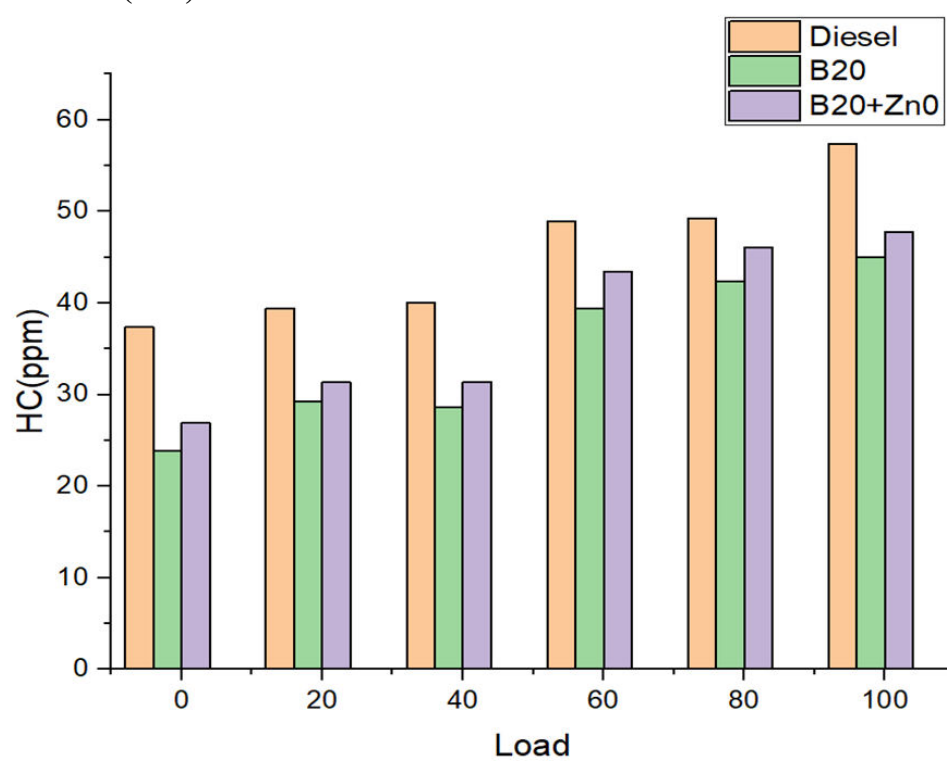

Figure 8: Variation of Hydrocarbon Emissons with Load

Figure 8 shows the variation of Hydrocarbon Emissions with Load. The presence of Nano additives acts as a binder and evades the undesirable fuel build up and crevice area penetration thus decreasing the HC emissions as seen in the Figure $8[39,40]$. The nanoparticle acts as oxygen buffer and supplies additional oxygen which aids formation of stoichiometric mixture. From the figure it can be seen that $\mathrm{ZnO}$ is more effective in reducing Hydrocarbon emission at higher loads. HC emission drops because of higher oxygen quantity of the blends which leads to improved overall combustion and higher cetane number which is provided by $\mathrm{ZnO}$ which enhances the combustion leading to lower hydrocarbon emissions

\section{Smoke Opacity}

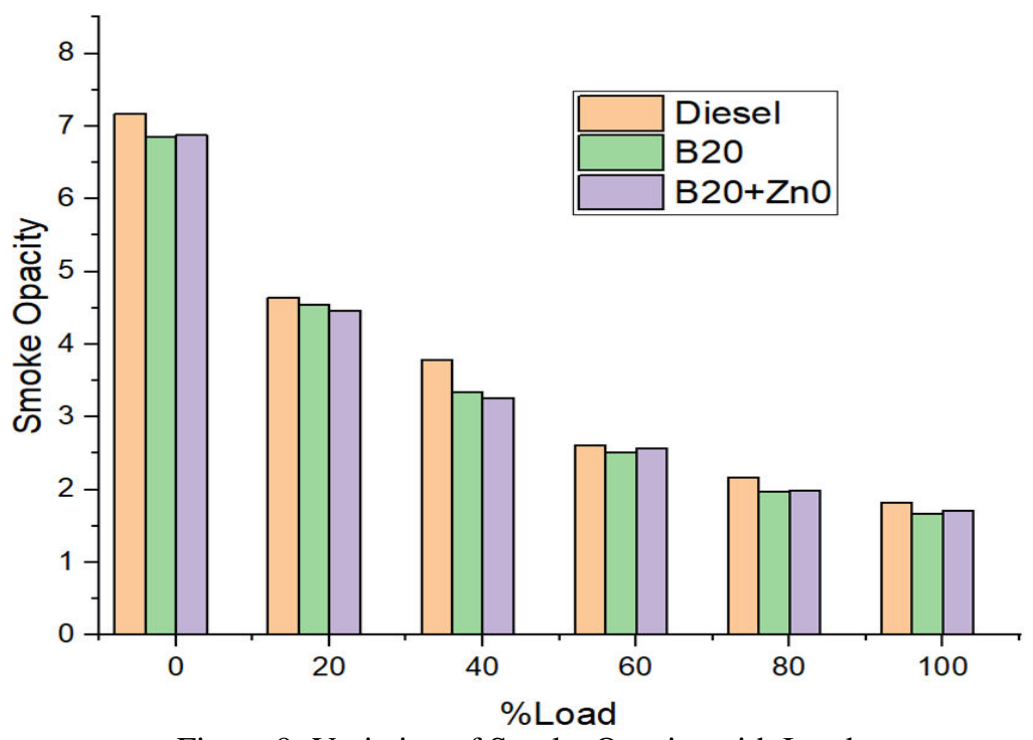

Figure 9: Variation of Smoke Opacity with Load 


\title{
International Advanced Research Journal in Science, Engineering and Technology
}

\author{
Vol. 6, Issue 11, November 2019
}

From the Figure 9 it can be seen that Smoke opacity falls by $8 \%$ for B20 when compared to diesel at full load and $3 \%$ for $\mathrm{B} 20+\mathrm{ZnO}$ when compared to diesel at full load. This is due to the advanced surface area -to - volume ratio of $\mathrm{ZnO}$ and greater cetane number causing complete combustion. Higher oxygen content in the blend enhances combustion and results in lowering of smoke emissions [41]. Also due to improved Sulphur and oxygen content of the nanoparticle blended fuel there is reduction of Smoke opacity [15]. Reduction of smoke opacity is because of the bonded oxygen which is higher in biodiesel compared to diesel that tends to reduce the soot formation $[42,43]$

\section{CONCLUSION}

1) Waste Cooking oil is abundantly available throughout the world and its disposal poses a great problem, but its potential as an alternate fuel is very promising. Transesterification has been employed to convert WCO to Biodiesel and also the properties have been evaluated according to the ASTM standard and the Biodiesel is compatible with diesel.

2) Heat release Rate is decreased by $6 \%$ for Biodiesel and $11 \%$ for the Zinc Oxide blend at full load when compared to diesel at full load because of the lower calorific value of the blend, and higher cetane number caused by addition of Waste Cooking Oil Methyl ester to diesel.

3) $\mathrm{P}-\theta$ shows that the maximum peak pressure for the biodiesel blends occurs at almost the same location, but the value of the maximum peak pressure at full load decreases by $10 \%$ for the $\mathrm{ZnO}$ blended biodiesel when compared to diesel as a result of high viscosity which is a consequence of adding nanoparticles into the biodiesel.

4) There is a decrease of $12 \%$ of the Brake Specific Fuel Consumption as Zinc Oxide acts as an oxidizing agent and improves the overall combustion process.

5) The occurrence of oxygen buffer which is gotten due to addition of Zinc Oxide nanoparticle results in the increase of Brake Thermal Efficiency by $3 \%$ at full load when compared to the baseline reading of diesel.

6) The unburnt Hydrocarbon and Carbon Monoxide emissions decrease by about $25 \%$ at full load when compared to diesel as a result of ignition delay as explained in the $\mathrm{P}-\theta$ diagram.

7) Nitrogen Oxides/NOx emissions decrease by about $14 \%$ as a consequence of oxygen absorption by the $\mathrm{ZnO}$ nanoparticle thus lesser oxygen is available for the formation of NOx.

8) Smoke opacity falls by $3 \%$ when compared to the baseline reading of diesel at full load due to improved surface area -to - volume ratio of $\mathrm{ZnO}$ and greater cetane number causing complete combustion.

Hence this fuel can be applied as an alternate fuel along with Zinc Oxide as the additive can be used for reducing emissons.

\section{REFERENCES}

[1]. Pinto AC, Guarieiro LL, Rezende MJ, Ribeiro NM, Torres EA, Lopes WA, "Biodiesel: an overview", J Braz Chem Soc 2005;16:1313-30.

[2]. Jaichandar.S, Annamalai.K," The status of biodiesel as an alternative fuel for diesel engine-an overview",J Sustain Energy Enviro 2013;2:71-5

[3]. Lapuerta, Herreros, José M. Lyons, Lisbeth L., Reyes Briceño, Yolanda, "Effect of the alcohol type used in the production of waste cooking oil biodiesel on diesel performance and emissions", 10.1016/j.fuel.2008.05.013

[4]. S.K. Hoekman, A. Broch, C. Robbins, E. Ceniceros, M. Natarajan, "Review of biodiesel composition, properties, and specifications", Renew. Sustain. Energy Rev. 16 (2012) 143-169.

[5]. S. Sivalakshmi, T. Balusamy, "Effect of biodiesel and its blends with diethyl ether on the combustion, performance and emissions"

[6]. Control of emissions from new marine Compression Ignition engines at or above 301 per cylinder, Assessment and Standards Division Office of Transportation and Air Quality. U.S. Environmental Protection Agency EPA-420-R-09-015; 2009.

[7]. A Report of International Energy Agency, OECD/IEA. 〈http://www.eia.gov/ forecasts/ieo/ exec_summ.cfm〉;2014.

[8]. Mu-Jung Kao, Chen-Ching Ting, Bai-Fu Lin, Tsing-Tshih Tsung, "Aqueous aluminum nanofluid combustion in diesel fuel", J. Testing and Evaluation 36 (2) (2008)

[9]. Chaturvedi S, Dave PN, Shah, "Applications ofnano-catalyst in new era", J Saudi Chem Soc 16:307-325

[10]. Wickham DT, Cook RL, De Voss S, Engel JR, Nabity J ,"Soluble nanocatalysts for high performance fuels”, J Russ Laser Res 27:552-561

[11]. Ramachandran SB," Ferrofluid-diesel blend", International Journal of Scientific and Research Publications. June 2015;5(6).

[12]. Selvaganapthy A, Sundar A, Kumaragurubaran B, Gopal P, "An experimental investigation to study the effects of various nanoparticles with diesel on DI diesel engine", ARPN J Sci Technol 2013.

[13]. Ozgür T, Tüccar G, Uludamar E, Yilmaz AC, Gungor C, Özcanli M, "Effect of nanoparticle additives on NOx emissions of diesel fuelled compression ignition engine", Int J Glob Warming 2015;4:487-98

[14]. Karthikeyan, "Performance and emission study on zinc oxide nano particle addition with pomolion stearin wax biodiesel of CI engine", J. Sci. Ind. Res. 73 (2014).

[15]. Karthikeyan, S Elango , " An environmental effect of GSO methyl ester with ZnO additive fuelled marine engine", Indian Journal of GeoMarine Sciences 564 Vol. 43(4), April 2014, pp. 564-570

[16]. Prabakaran, "Investigation of effects of addition of zinc oxide nano particles to diesel ethanol blends on DI diesel engine performance, combustion and emission characteristics", Int. J. Chem. Sci. 13 (3) (2015) 1187-1196.

[17]. Prabakaran,'Effect of nano zinc oxide on the performance, combustion and emission characteristics of biofuel blends in diesel engine", Int. J. Appl. Eng. Res. 10 (91) (2015), ISSN 0973- 4562

[18]. Arvind K.,Madheshiyaa B., Ajitanshu V., "Energy-exergy analysis of biodiesel fuels produced from waste cooking oil and mustard oil", Vol. 214,pp. 386-408.Fuel(2018).

[19]. Sadhik B. J., Anand R.B., "Effects of Alumina Nanoparticles Blended Jatropha Biodiesel Fuel on Working Characteristics of a Diesel Engine",ISSN 0974-3146 2010; 2:53-62. 


\title{
International Advanced Research Journal in Science, Engineering and Technology
}

\author{
Vol. 6, Issue 11, November 2019
}

[20]. Kakoee, A., Bakhshan, Y., Motadayen Aval, S., Gharehghani,”An improvement of a lean burning condition of natural gas/diesel RCCI engine with a pre-chamber by using hydrogen", Energ. Convers. Manage. 166, 489-499.

[21]. [21] Murlidharan, K. and.Vasudevan, D;" Performance, emission and combustion characteristics of a variable compression ratio engine using methyl esters of waste cooking oil and diesel blends", Applied energy 2011; 88:3959-3968.doi:10.1016/ j.apenergy. 2011. 04.014

[22]. Das SK, Choi SUS, Yu W, Pradeep T,'Nanofluids: science and technology” Wiley, Hoboken, pp 10-11

[23]. Sadhik Basha J, Anand RB ,"An experimental investigation in a diesel engine using CNT blended water-diesel emulsion fuel”,Proceedings of I Mech E. Part A. J Power Energy 225:279-288

[24]. Sayin C, Ilhan M, Canakci M, Gumus M," Effect of injection timing on the exhaust emissions of a diesel engine using diesel methanol blends", Renew Energy 2009;34:1261e9.

[25]. Puhan S, Jegan R, Balasubbramanian K, Nagarajan G," Effect of injection pres- sure on performance, emission and combustion characteristics of high lino- lenic linseed oil methyl ester in a DI diesel engine", Renew Energy 2009;34: 1227e33.

[26]. Sabourin, J.L., Daniel, M.D., Yetter, R.A., Frederick, L.D. and Ilhan, A.A., "Functionalized graphene sheet colloids for enhanced fuel/propellant combustion" ACS Nano, Vol.3, 3945-3954, 2009.

[27]. Selvan VA, Anand RB, Udayakumar M," Effects of cerium oxide nanoparticle addition in diesel and diesel-biodiesel-ethanol blends on the performance and emission characteristics of a CI engine", J Eng Appl Sci. 2009 (7):1819-6608.

[28]. Basha JS, Anand RB," Performance, emission and combustion characteristics of a diesel engine using carbon nanotubes blended jatropha methyl ester emulsions", Alexandria Engineering Journal. 2014; 53(2):259-73.

[29]. M.Vijay KumarA, Veeresh Babu, Ravi Kumar, "The impacts on combustion , performance and emissions of biodiesel by using additives in direct injection diesel engine", Alexandria Engineering Journal, http://dx.doi.org/10.1016/j.aej.2016.12.016

[30]. May WR, Hirs EA," Catalyst for improving the combustion efficiency of petroleum fuels in diesel engines", 11th diesel engine emissions reduction conference, August 21-25; 2005. Chicago II

[31]. Burtscher H, Matter U, Skillas G," The effect of fuel additives on diesel engine particulate emissions", J Aerosol Sci 1999;30:851-2.

[32]. Kim SH, Fletcher RA, Zachariah MR," Understanding the difference in oxidative properties between flame and diesel soot nanoparticles: the role of metals",Environ Sci Technol 2005;39:4021.

[33]. Jung H, Kittelson DB, Zachariah MR," The influence of a cerium additive on ultrafine diesel particle emissions and kinetics of oxidation", Combust Flame 2005; 142:276-88

[34]. Ashok, B.Nanthagopal, K. Mohan, Aravind Johny, Ajith Tamilarasu ,"Comparative analysis on the effect of zinc oxide and ethanox as additives with biodiesel in CI engine", 10.1016/j.energy.2017.09.021

[35]. Soudagar,M Kalam, AbulBadruddin, Banapurmath,Akram,Naveed,"The effect of nano-additives in diesel-biodiesel fuel blends : A comprehensive review on stability,engine performance and emission characteristics The effect of nano-additives in diesel-biodiesel fuel blends", Energy Conversion and Management, 10.1016/j.enconman.2018.10.019

[36]. Prabakaran, B.Vijayabalan,"Influence of zinc oxide nano particles on performance, combustion and emission characteristics of butanol-dieselethanol blends in di CI engine", IOP Conference Series: Materials Science and Engineering, 10.1088/1757-899X/377/1/012069

[37]. Shaafi, T. Sairam, K. Gopinath, A. Kumaresan, G.Velraj,'Effect of dispersion of various nanoadditives on the performance and emission characteristics of a CI engine fuelled with diesel, biodiesel and blends-A review”, Renewable and Sustainable Energy Reviews,0016-2361

[38]. Chauhan BS, Kumar N, Cho HM,"A study on the performance and emission of a diesel engine fueled with Jatropha biodiesel oil and its blends", Energy 2012;37 (1):616-22.

[39]. Venu, Harish Madhavan,Venkataramanan,'Effect of Al 2 O 3 nanoparticles in biodiesel-diesel-ethanol blends at various injection strategies : Performance, combustion and emission characteristics", doi.org/10.1016/j.fuel.2016.08.046

[40]. Schmidt K, Van Gerpen JH,'The effect of biodiesel fuel composition on diesel combustion and emissions",SAE paper 9610861996.

[41]. Wang WG, Lyons DW, Clark NN, Gautam M, Norton PM, "Emissions from nine heavy trucks fuelled by diesel and biodiesel blend without engine modification", Environ Sci Technol 2000;34(6):933-9.

[42]. Boehman AL, Song J, Alam M," Impact of biodiesel blending on diesel soot and the regeneration of particulate filters", Energy Fuels 2005; 19:1857-64. 